AUTHOR:

Prof M. Koen ${ }^{1}$

Dr M.M. Neethling ${ }^{1}$

Dr S. Esterhuizen ${ }^{1}$ (iD)

Mrs B. Taylor ${ }^{1}$ (D)

AFFILIATION:

${ }^{1}$ North West University, South Africa

DOI: http://dx.doi. org/10.18820/2519593X/pie. v39.i1.9

e-ISSN 2519-593X

Perspectives in Education

2021 39(1): 138-156

PUBLISHED:

12 March 2021

RECEIVED:

9 November 2020

ACCEPTED:

23 January 2021

\section{THE IMPACT OF COVID-19 ON THE HOLISTIC DEVELOPMENT OF YOUNG SOUTH AFRICAN AT-RISK CHILDREN IN THREE EARLY CHILDHOOD CARE AND EDUCATION CENTRES IN A RURAL AREA}

\begin{abstract}
Early childhood care and education (ECCE) has gained recognition as an important means of promoting the holistic development of the inseparable social, emotional, cognitive and physical facets of education in the early childhood years. Since early childhood development poses challenges to many young children, the prolonged mandatory closure of ECCE centres during the national lockdown exposed many young children to the additional risk of being deprived of the continuity of learning, security, health and safety. This article draws from a research project in three Bafenyi ECCE centres in the rural area of Ikageng (Potchefstroom) in the North-West province of South Africa and focuses on how COVID-19 influences the holistic development of young children at risk. A qualitative approach was taken, following a participatory actionlearning and action-research (PALAR) design where all participants collaborate as equal partners and construct their own meaning from experiences within the action-learning set (ALS) to advocate for change. Within a critical and transformative paradigm teacherparticipants were encouraged to think critically about the holistic development of young children and to consider how collaboration could lead to social change. The data collection method was limited to the recorded group discussions of the ALS during Cycle 1 of the PALAR process. Given that positive environmental and contextual factors are able to lay the groundwork for holistic development in the early years, the African Ubuntu philosophy of compassion, respect and humanity was viewed as being suitable to serve as theoretical framework for the study. The findings highlight that, even during a lockdown, it vital that collaborative ways are found to harness the precious early years with a view not only to meeting these children's needs but also to laying the foundation for a sustainable future. It is argued that if teachers were to apply the Ubuntu philosophy, they would learn how to make lifelong use of the acquired skills to improve the holistic well-being of young children on an ongoing basis.
\end{abstract}

Keywords: Early childhood; COVID-19; education; holistic; sustainable; ubuntu. 


\section{BACKGROUND TO THE STUDY}

It is generally argued that the measures to prevent and contain the spread of COVID-19 have implications for everybody, everywhere. The coronavirus does not respect national borders and, regardless of race, religion, class or nationality, we can all potentially be infected (Ndebele \& Sikuza, 2020).

Beyond the obvious physical consequences of the infection, the pandemic has had a severe impact on people's holistic well-being. Although young children seem less susceptible to the physical symptoms, Prof Eric Atmore, the director of the Centre for Early Childhood Development (ECD), is concerned about the holistic well-being of the 2.3 million young South African children who were housebound during lockdown (Masweneng, 2020). Globally, the containment measures that triggered school closures negatively affected the socio-emotional, cognitive and physical well-being of over 1.5 billion children (Devercelli, 2020; UNESCO 2020c). The extent of the long-term damage to the holistic development of children caused by the closure of schools and early childcare centres cannot yet be determined. It is however expected that the effects will be most damaging to children in the early years who live in the poorest societies, especially those young children already deprived or living in vulnerable situations (Makhubu, 2020; UNESCO, 2020b). According to Flynn (2020), even before the pandemic, $43 \%$ of children younger than five years of age were already estimated to be at risk or unable to achieve their developmental potential. This pre-existing inequality has now increased dramatically because of the COVID-19 containment measures. The school closures additionally exposed vulnerabilities in social, political and economic structures, which could have a lifelong impact on the holistic development of children (UNESCO, 2020b).

The foregoing discussion has emphasised the fact that optimal development in the early years calls for a stimulating and enriching environment, adequate nutrition, learning opportunities and social interaction (UNICEF, 2020). Against this backdrop, four researchers embarked on a research project in March 2020 in three Bafenyi ECCE centres in a rural area of Ikageng in Potchefstroom, South Africa. The purpose of this study was not to generalise but to gain an understanding of how the physical (P7), cognitive (P6), social and emotional domains (P5) influence the holistic well-being of young children in the relevant centres, and how a play-based approach (P8) could contribute to the creation of potential learning opportunities in the different domains (see Table 1). Four researchers were involved in the project because each researcher planned to focus on one of the abovementioned focus areas. The COVID-19 lockdown restrictions compelled us (the researchers) to conduct the research online. In the process of the investigation, we realised that the restrictions and forced school closures during lockdown added additional pressures to the holistic well-being of young children. The research question was therefore rephrased accordingly: How does COVID-19 influence the holistic development of young children at risk?

While optimal holistic development in the early years comprises the influence of intrinsic and extrinsic factors, many children in the early years are deprived of a nurturing and caring parent-child environment (Gumbi, 2019). Given that positive environmental and contextual factors can potentially lay the groundwork for holistic development in the early years, we deemed the African Ubuntu philosophy of compassion, respect and humanity to be suitable to serve as theoretical framework for the study. In this paper, we argue that using this theory could provide opportunities - by means of collaboration between the school and the community - for engaging young children in activities that stimulate development in the physical, 
socio-emotional and cognitive domains. We concur with Rampke (2016) that the term Ubuntu may be open to alternative interpretations and approaches in different communities. In this study, the term Ubuntu has been chosen to reflect an awareness of the spirit of compassion and care to cultivate holistic development in the early years in the Bafenyi community. Because Mushaandja (2015) moreover cautions against the common practice of using the term without clarity and substance, our purpose was therefore not to present Ubuntu as a seamless way to guarantee holistic well-being for all young children, but rather to investigate how the implementation of this theory could serve as a means not only of minimising but also of protecting young children against the harmful effects of containment.

In the first section, the relevant literature is explored with a view of identifying the potential damage caused to the holistic well-being of young children by the closure of early childcare centres. Next, we turn to exploring how applying the Ubuntu philosophy could act as social ideal that encompasses the holistic development of young children at risk in three Bafenyi ECCE centres. Then we explain how the research question was addressed by employing a PALAR research design to address the issues that affect the lives of young children collaboratively. We present the findings by the relevant integrating literature with a discussion to substantiate ideas offered by participants. In our conclusion, we emphasise the need for teachers, parents and caregivers to collaborate and to find creative solutions in respect of providing South Africa's most vulnerable young citizens with the education they deserve.

\section{LITERATURE REVIEW}

In South Africa, the Department of Education's White Paper 5 (2001) uses the umbrella term early childhood development (ECD) to describe the holistic process by which children from birth to at least nine years of age grow and thrive physically, mentally, emotionally, spiritually, morally and socially (DBE, 2001). In the present paper, the focus is on children from birth to four years of age. Since evidence indicates that more than 80 per cent of a child's cumulative brain development happens in the first three years of life, these are globally recognised to be the most crucial years for lifelong development (ETDP-SETA, 2020; Peckham, 2017; UNICEF, 2020). Researchers agree that early childhood care and education (ECCE) includes much more than merely the preparation for primary school. They emphasise that it is an important means of nurturing future citizens who will be caring, capable and responsible (Warwick, Warwick \& Nash, 2018). They further add that holistic development in the early years is shaped by opportunities to conceptualise, think critically, participate with others and to reflect (Warwick, Warwick \& Nash, 2018). Young children who are deprived of holistic development are at risk of experiencing cognitive, social, emotional and health problems (Fourie \& Kgalenga, 2014). For this reason, quality education in the early years should provide opportunities for significant development in the inseparable social, emotional, cognitive and physical needs of young children (Bennett \& Palaiologou, 2016). This is why government officials, researchers, stakeholders, teachers and parents are worried that the outbreak of the coronavirus has not only changed the lives of hundreds of millions of children across the world, but that it will further place education on hold indefinitely (Egan, 2020; Pedro, Mthimunye \& Bust, 2020).

In South Africa, the prolonged mandatory closure of ECD centres (including ECCE centres) during the national lockdown changed the daily routines and domestic dynamics of many young children and placed them at risk of being deprived of the continuity of learning, security, health and safety (Pedro, Mthimunye \& Bust, 2020). What particularly concerns Makhubu (2020) about a report entitled The plight of the ECD workforce (April 2020) is that it projects 
how the numbers of young children who are supposed to be receiving quality education had dropped from 5 million to 1.5 million as a result of containment measures. Researchers are concerned that COVID-19 not only halted the economy, but that unemployment, a lack of social nets and crowded housing added to the financial strain (Flynn, 2020). In addition, the financial shortages required many ECCE centres to close or to lay off teachers and other staff, thereby increasing the vulnerabilities of young children who desperately need care and stimulation (Makhubu, 2020; Masweneng, 2020). Young children were housebound during the lockdown and parents, grandparents, guardians or caregivers were forced to care for, nurture and teach them while many of them were themselves not equipped to meet the young children's holistic developmental needs (UNICEF, 2020). Some living environments were moreover characterised by a lack of appropriate resources, learning opportunities and social interaction. These circumstances resulted in lost learning time that placed the children's holistic development at risk (Makhubu, 2020). Bennett and Palaiologou (2016) are convinced that the quality and quantity of resources and access to toys and play materials have a major impact on young children's physical, social, emotional and cognitive development. Researchers are also concerned that vulnerable children could become victims of crime and abuse if they are not able to spend their daily lives in the safety of ECCE centres (Masweneng, 2020).

It is expected that the ripple effects of the circumstances outlined above are set to compromise the healthy development trajectories of children in the early years in that they may have spill over effects on the development of the holistic domains (Buheji et al., 2020). As a result of lockdown, most young children were deprived of interaction and playing with other children. This could influence physical-activity behaviours (Chen et al., 2020). Young children will furthermore be returning to a changed physical environment characterised by restrictions aimed at minimising health risks, promoting safety and prescribing with whom they may interact or play (Egan, 2020). The situation is further exacerbated if children are confined to their homes where they have no access to outdoor activities or interaction. All these factors could potentially lead to weight gain in children, and to various social and emotional problems (Buheji et al., 2020). The lack of social interaction could also limit the development of independent thinking, a sense of belonging and relationship skills (Peckham, 2017). The lack of social-emotional skills may consequently impact on personal development and can also have a significant effect on the future academic achievement of young children (Bennett \& Palaiologou, 2016).

In this paper, the African Ubuntu philosophy is used as a theoretical approach to orientate this research project and to guide us on important issues that could contribute to the holistic well-being of children in their early years. While research emphasises that all young children have the right to develop to their full potential, it is evident that holistic development is determined by the learning opportunities afforded to young children (Peckham, 2017). In addition to challenges posed by unequal opportunities, many young children are experiencing further restrictions and unprecedented challenges resulting from the COVID-19 pandemic (Flynn, 2020).

\section{THEORETICAL FRAMEWORK}

The rationale for applying an Ubuntu philosophy lies in the ideas of interconnectedness, sharing, caring and collaboration (Mugumbate \& Cherini, 2019). The theoretical framework of Ubuntu served as a nurturing tool for collaboration to create learning opportunities for young children in the three Bafenyi ECCE centres. This idea is in line with Norren's (2014) 
suggestion that positive interactions between the young child, school, families and caregivers could embrace an Ubuntu approach in early childhood development by providing opportunities to extend the holistic development of children. Applying an Ubuntu approach may thus create learning opportunities by strengthening the interaction between teachers, parents and caregivers to lay the foundation for learning experiences that influence children's holistic wellbeing and, ultimately, their future lives. It is also argued that not take collaborative action against COVID-19 challenges may adversely affect the already at-risk children.

Considering this view, Ubuntu has been linked to the phenomenon of holistic well-being in the early years. According to Bondai and Kaputa (2016), the holistic development of the whole child is underpinned by the Ubuntu philosophy in which different facets of life feature as part of an indivisible whole. It is explained that "Umuntu ngumthu ngabantu" is a Nguni philosophy, a way of being and a moral code (Afrika Tikrun, 2020). These words are translated as "I am because we are", and this notion is understood as "a person is a person through other persons" (Ndebele \& Sikuza, 2020:1-3). The Ubuntu idea can be translated and explained as a common humanity, one that suggests that a "person becomes a person" through other people (Wooldridge, 2020:1-2). In other words, it signifies an integrated action in which people live in harmony and operate amidst a shared humanity and interconnectedness. Mushaandja (2015) adds that the survival of human beings needs to be strengthened by connection. This idea could suggest that by focusing on the strength of connections, the adversity of COVID-19 can be addressed. In this way, governments, departments, policies, communities, caregivers, parents and teachers become pathways to personhood by being collectively responsible for one another's well-being (Mugumbate \& Chereni, 2019; Phasha, 2016).

Wilemon (2020) illustrates the above sharing view by arguing that all of us are together in this pandemic: we are one. For some, the pandemic is a reminder of our nation's oneness, that we are all equally human and that we are interconnected and dependent by virtue of our shared human mortality (Ndebele \& Sikuza, 2020). Thus, in order to face the real enemy in these challenging times, we all have to work together by practising the principles of Ubuntu (Ndebele \& Sikuza, 2020). According to Mamanzi (2020), a revitalisation of Ubuntu during COVID-19 could instil the value and significance of a shared responsibility. It was suggested that embracing the Ubuntu philosophy in our study could result in educational change influencing the socio-emotional, cognitive, spiritual and physical development of young children in the Bafenyi ECCE centres.

Rampke (2016) cautions that - from a Western perspective - there might be barriers to an understanding of Ubuntu. While we concede that applying Ubuntu will not make all the risk factors created by the COVID-19 pandemic disappear, we do believe that some of the challenges could potentially be avoided by promoting positive interactions between significant adults with a view of improving the holistic development of young children.

\section{RESEARCH METHODOLOGY}

Qualitative studies assume that participants construct their own knowledge and meaning from experiences (Bertram \& Christiansen, 2020). This study is situated in a qualitative research approach as the purpose of the research was to investigate the meaning participants assign to the holistic development of young children. 


\subsection{Context of the study}

Bafenyi is the Tswana word for "winners" and the Bafenyi Trust provides early childhood programmes to bring hope and love to communities that are in desperate need of these qualities (Bafeyni Trust, 2021). The study was limited to a specific group of eight participants between the ages of 35 and 56 years, comprising three Setswana-speaking principals from three Bafenyi ECCE centres, four Afrikaans-speaking researchers and a gatekeeper in Ikageng, a rural area in North-West province of South Africa. All three principals fulfil the dual role of a teaching principal and we will refer to them simply as teachers. As suggested by McAreavey and Das (2013), the gatekeeper negotiated directly with the research participants and acted as mediator to enhance the trust relationship in the ALS. The participants were purposively selected to form part of the ALS to allow the researchers to work in a small group and to gain a deeper understanding of the research problem (Leedy \& Ormrod, 2015). Threeweekly Zoom meetings, each lasting approximately 45 minutes, enabled the ALS to discuss, share and reflect openly on the main research question, namely how COVID-19 influences the holistic development of young children at risk.

\subsection{Research design}

Taking a qualitative approach as our point of departure, participatory action learning and action research (PALAR) was used as the research design because it allowed us to engage in a collaborative action-learning research process (cf. Zuber-Skerritt, 2019). Any form of participatory action research goes further than the mere understanding of the research problem, as all participants collaborate as equal partners within the action-learning set (ALS) to advocate for change (Wood, 2020). Within a critical and transformative paradigm, the participants were encouraged to think critically about the holistic development of young children and to consider how collaboration could lead to social change. This idea is in line with the thinking of Cohen, Manion and Morrison (2013) who have argued that a critical paradigm introduces participants to new possibilities while examining the social reality of collaboration. In order to establish the collaborative role of participants, the three Rs suggested by ZuberSkerritt (2011) were employed, namely a trusting relationship, continual critical reflection and recognition of the learning generated by the participants.

The PALAR process usually consists of more than one cycle where a research question is addressed during each cycle (Wood, 2020). While the purpose of the research project initially was to investigate the holistic development of young children by rolling out three cycles, the restrictions during COVID-19, highlighted the impact of the school closures on the development of young children at risk in the early years. Therefore, the main research question was adapted to determine the nature of the challenges that teachers are facing in terms of supporting the holistic well-being of young children in the three Bafenyi ECCE centres in the light of the impact of COVID-19. The first cycle comprised four recorded action-learningset (ALS) sessions, which included a start-up workshop for organising the group; exploring and negotiating the role of participants and conducting a needs analysis. In an attempt to answer the main research question, the following secondary questions arose, namely, 1) what the factors are that influence the holistic development of young children in the three Bafenyi centres? and 2) how can these challenges be addressed to enhance the holistic development of the young children in the three ECCE centres?

While reflecting on the factors that influence the holistic development of young children in the specific centres during COVID-19, the significant role played by teachers, parents and 
caregivers in stimulating young children's holistic development was foregrounded. These ideas led to the organising of the Singakwenza Workshop. Singakwenza (meaning "we can do it" in isiZulu) is a charity organisation in KwaZulu-Natal, South Africa, which aims to provide nurturing learning dispositions by stimulating young children through play (News 24, 2020). Indeed, the Ubuntu philosophy not only forms part of the knowledge and wisdom of Afrocentric policies, but it also embodies a collaborative care approach (Lefa, 2015). The ALS followed the idea proposed by Mamanzi (2020) that perhaps the cohesiveness of the community of Ikageng could respond to the pandemic as a social action that aims to work collaboratively to influence the holistic development of young children. Wood (2020) indeed proposes that the action-learning component of the ALS foreground the notion that participants acquire the skills of lifelong learning to develop potential that would stretch beyond the scope of a specific project. It was argued that the Singakwenza Workshop could involve teachers, parents and caregivers in the Bafenyi community when they learn how to make educational toys from recycled materials. Although we realised that Ubuntu would not make all the COVID-19 challenges disappear, Oladokun's idea (2020) that 2020 was a perfect time for a collaborative approach seemed worth trying.

\subsection{Data analysis and ethics}

A thematic-analysis approach was used to analyse the data according to Braun and Clarke's (2013) six-phase steps. This process entailed familiarising ourselves with the data; coding, segmenting and searching for themes; reviewing, defining and organising the views of participants according to themes and, finally, substantiating the findings with participants' verbatim quotations. To ensure credibility, the five quality indicators as set out by Herr and Andersen (2005) were employed, namely outcome validity, process validity, democratic validity, catalytic validity and dialogue validity.

The Ethics Committee of the North-West University and the Department of Education and Sport Development of the North West Province both granted ethical clearance and permission to conduct the low-risk-level research project. Given that PALAR's vision and principles cannot be adhered to unless participants are well informed, committed and feel engaged (Zuber-Skerritt, 2011), the research was conducted in a participatory, collaborative manner. Even though no participant's input could be private, autonomy was ensured by respecting one another's voices and one another's rights and opinions. Ethical issues were negotiated with participants during the Pre-cycle Phase (relationship building). Voluntary participation was thus ensured and participants were required to sign a letter of consent prior to participation. The gatekeeper, a person known to all the participants, screened all the correspondence from the researchers. It was clearly explained that the participants could withdraw from the study at any time should they not feel comfortable with participating in the research. The data were stored electronically by using password-protected documents on Google Docs and are to be destroyed within the timeframe indicated by the North-West University record system.

In the next section, the findings will be presented in an integrated manner, in response to the questions addressed by the ALS.

\section{FINDINGS AND DISCUSSION}

In presenting the data, we have numbered the female members of the ALS from P1 to P8. The 1-3 verbatim statements of participants have been used to reflect the originality of the information we have collected. Table 1 below summarises the biographical details of the ALS: 
Table 1. Biographical details of the ALS

\begin{tabular}{|l|l|l|l|}
\hline Participant code (P) & Race & Home Language & Professional status \\
\hline P1 & Black & Setswana & Teacher 1 \\
\hline P2 & Black & Setswana & Teacher 2 \\
\hline P3 & Black & Setswana & Teachers 3 \\
\hline P4 & White & Afrikaans & Gatekeeper \\
\hline P5 & White & Afrikaans & Researcher \\
\hline P6 & White & Afrikaans & Researcher \\
\hline P7 & White & Afrikaans & Researcher \\
\hline P8 & White & Afrikaans & Researcher \\
\hline
\end{tabular}

From the data it is apparent that a multitude of factors influence the holistic development of young children. We now turn to a discussion of the themes that emerged from the data (see Figure 1). Relevant literature and verbatim statements will support each theme.

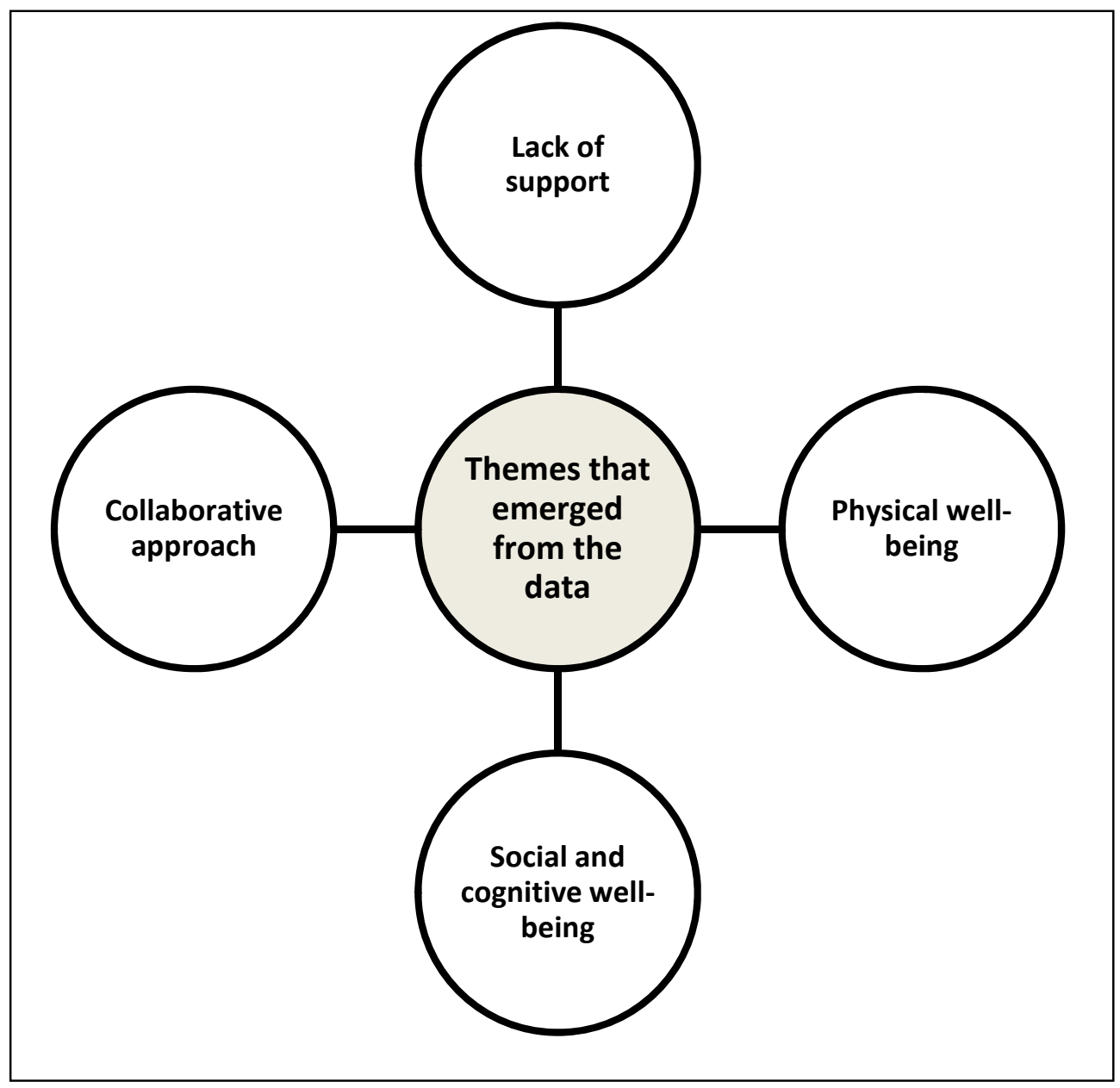

Figure 1: Themes that emerged from the data. 


\subsection{Lack of support}

Before lockdown it was already apparent that reaching marginalised young children and providing them with access to quality education represented a key challenge to the South African state and non-governmental organisations (NGOs) (EDTP-SETA, 2020). In the South African Early Childhood Review (2019), for instance, it is stated that the leading actors in the South African education system are failing the majority of the country's children in that in excess of one million 3- to 5-year-olds are excluded from early childhood developmental programmes across the country. Researchers agree that ECCE centres lack adequate access to governmental support, are poorly capacitated and are moreover under-resourced (Barker \& Misselhorn, 2014; Harrison, 2020). It would appear that, as from the beginning of March 2020, South Africa's already overburdened government departments now also had to face increased challenges brought on by the financial strain of the pandemic (Eastern Cape News, 2020). In addition to other requirements, they now also had to adhere to the standard operating procedures (SOP) for the prevention, containment and management of COVID-19 issued by the Department of Basic Education (DBE) and the Department of Social Development (DSD). While there were extremely strict rules to follow, the departments in question failed to provide ECCE centres with the necessary personal protective equipment (PPE) or adequate training opportunities regarding COVID-19 safety measures (Masweneng, 2020). Because the said departments moreover failed to respond telephonically or in person to enquiries, this complicated the process of opening centres. As one participant explained:

P2: When the Minister said we can open, I'm a little bit worried; now the reason is, number one l'm not yet ready and l'm also not trained to receive kids. Yes, we have been receiving so many documents from social development and really I needed training.

Another participant added:

P3: We cannot open because the readiness of our schools are [is] not in place like the sanitisers and stuff PPEs and everything.

It appears as if ECCE centres had generated no income for months because parents had stopped their payments (Masweneng, 2020). One of the practitioners voiced her frustration because they did not receive funding from the DBE and the DSD was struggling to make ends meet. The participant explained that ECCE centres were unable to buy COVID-19-related detergents and masks for the staff and children:

P3: The Department of Education and again Social Development doesn't help any school until today, because l've ask around and nobody gets any help from them, especially with the materials, the essentials of COVID-19, like your mask and all those other things. So we are really like (laughing) we are trusting God to make a way for us all ECDs 'cause there's no one who gets any help from any Department, Social Development; also [the] Department of Education.

A lack of informative guidelines, of relevant psychosocial support and of resources during lockdown widened the existing significant education gap of all children younger than five years of age (Flynn, 2020). Researchers are concerned that COVID-19 has not only halted the economy, but that unemployment, a lack of social nets and crowded housing have added to the financial strain (Flynn, 2020). 
Another problem with which the teachers were confronted was the enormous administrative load they were required to bear. They received no guidance from the authorities regarding the completion of tasks and the creation of precautionary protocols.

P2: The COVID-19 file, it's ... uh ... really a challenge because there's so many things that they want there. We must print out policies and print out the ... uh ... trainings, especially the COVID-19 training and they also want ... uh ... staff ... uhm ... precaution protocols and everything, so we are not yet open.

The above discussion underlines the fact that the teachers experienced anxiety and fear regarding the reopening of schools, administration and also the development of the young children. The above comments serve to emphasise the fact that the holistic well-being of three Bafenyi teachers was also affected by much strain experienced during lockdown. It appears that while they were concerned about the well-being of the young children, they also feared being closed down if their centres failed to observe the COVID-19 rules. The sharing of feelings and emotions pointed to the teachers' dire need for support. This idea is in line with Takyi-Amoako and Assié-Lumumba (2018) who maintain that, in an Ubuntu approach, the focus on support and togetherness takes precedence over individuality. While we are aware that Ubuntu will not fulfil all the holistic needs of young children, we nevertheless believe that togetherness, sharing and caring could potentially provide opportunities to enhance holistic well-being.

\subsection{Physical well-being}

Holistic development in the early years requires a healthy lifestyle that sustains physical, cognitive, social and emotional well-being (Peckham, 2017). Without nutritious meals, children's physical, cognitive, emotional and social development are at risk of not developing as they should. Their immune systems weaken and render them susceptible to illnesses. Because the children in their ECD centres were accustomed to receiving two nutritious meals daily, the participants were concerned that the children would go hungry or that they would not have nutritious food during the winter months.

$\mathrm{P} 1$ : Some of they [parents] were asking if maybe we can do like a food for them. Then they must just come and get food and go home. At least that it would help them.... they were asking like when the creche is opening. Our children are hungry. You know mos, when they are at the centre, [this] is where they get something to eat for the whole day.

Participants added that with the help of donations, 200 families could be fed twice per day (400 food parcels). The food parcels, distributed from ten drop-off points, contained essential foods, such as maize, beans and milk, and detergents.

Besides fears regarding children's' health, a further concern is that vulnerable children could become victims of crime and abuse if they are not able to spend their daily lives in the safety of ECCE centres (Masweneng, 2020). Children's safety was a critical concern for all participants because children were unattended and roaming the streets without warm clothes, masks or shoes. They were vulnerable to crime and abuse. One concerned participant had the following to say:

P3: The children they don't even stay at home even ... every morning you go outside, they are playing, they are running around. They don't even wear warm clothes like shoes. Some of them they are like ... uh ... barefoot.

Another participant stated: 
P2: It's breaking my heart, you know. We saw this child in the street, it was cold, it was really cold, colder than today. That child - it is a 2-year[-old] child - didn't wear anything and that child was walking past us, crying. We didn't know who the parents was [were], no one was with this child.

Participants agreed that the children were better off at school where they were safe, fed and warm.

P1: I don't know what to say because of you see this [these] children. If they were at school, they will be safer than being at home. Now I can say that in school it will be safer for the children.

They experienced conflicting emotions in respect of whether to open their centres for the children's safety.

P3: When I don't open, I can see this [these] children suffering. No one [is] supervising them, children are not stimulated, children are not being educated, children are suffering, and they are actually [the] victims. Victims of ... joh ... crimes and all these things.

Bennett and Palaiologou (2016) maintain that the quality and quantity of resources, especially access to toys and play materials, have a major impact on young children's physical, social, emotional and cognitive development. Participants were therefore not only concerned about effectively sanitising their schools, and about the provision of soap, sanitisers and masks for staff and children, but were also apprehensive because they had to remove all the soft toys from their classrooms. One of the teachers shared this concern:

P2: [During] COVID-19 we have removed all the toys that were there ... uh ... especially the soft toys and it's a challenge because these soft toys are actually the dolls and the ... the ... uh ... teddy bears, neh. And they are soft and they say... uh ... that we cannot ... uh ... keep them for now with the COVID-19, with the virus. So, for me, I think the need will be, yes, to make ... uhm ... recycled material toys for the babies.

The above statements underline the fact that teachers are worried about how COVID-19 has affected opportunities for young children to be physically active and to have a supportive network to facilitate their activities. While the teachers were worried about the health of young children, they realised that the physical aspects could also have an impact on the various inseparable facets of well-being.

\subsection{The cognitive and socio-emotional well-being of children}

Holistic development in the early years is shaped by opportunities to conceptualise, think critically, participate with others and to reflect (Warwick, Warwick \& Nash, 2018). Teachers expressed concern regarding children's social interaction as a result of COVID-19. The fact that children were at home where they were deprived of constructive play with peers, might impede their cognitive and socio-emotional development (Egan, 2020). Participants explained that while the teachers did indeed send activities to the parents of the children in their centres during the lockdown, the parents failed to do the activities with their children, their excuse being that they did not understand how to do the activities. The teachers believed many of the parents in the informal settlements do not really care about the well-being of their children.

P3: I know parents are very negative sometimes. And our parents, most of the time, $80 \%$ of them are very negative. They don't want to work towards ... uhm ... maybe helping all the kids at school. 
The above comment suggests that parents did not always assist their children to do activities sent from school. Another teacher explained:

P1: My experience ... with sending maybe work to the parents - it was actually not worth it, because they didn't understand the activities and so on and I just stop to do, to send work to them.

The above discussion highlights that school closures and the consequent delegating of the educational role to parents and/or caregivers have been responsible for this. While parents and caregivers are in the best position to support the holistic development of young children, the participants stated that many parents experienced challenges in respect of supporting children academically or financially. Another participant stated:

P1: Some of them you could even see that they were not interested to do the activities with their kids.

It is therefore argued that ECCE centres could be creative about the way they develop collaborative educational interventions to stimulate the holistic development of young children. Given that the Ubuntu philosophy involves characteristics such as collaboration, social responsibility and sharing (Mugumbate \& Cherini, 2019), it is argued that involving communities in the making of educational toys from recycled materials could be a first step towards acknowledging the human worth in communal relationships. During the reflection stage, the ALS suggested that involving parents in the making of recycled educational toys might encourage them to commit to doing the activities sent from school with their children. In order to address this need, the ALS organised a Singakwenza workshop aimed at teachers, parents and caregivers at the grassroots level to develop young children holistically by involving the community in using recycled materials (Singakwenza, 2020).

\subsection{Collaborative approach}

Singakwenza runs a "Waste2Toys" project that provides stimulating opportunities for communities to guide its members in the process of preparing young children for formal school (News24, 2020). Hay (a Singakwenza board member) believes that although it is not possible to change the perceptions of all the people, it is however worthwhile to create opportunities to change the future of one young child (Singakwenza, 2020). At the end of the Singakwenza Workshop, it was decided that recycling bins would be put outside the school gate so that parents could contribute usable refuse for the making of toys. One of the teachers suggested:

P2: I'm thinking also that we can also ... uh ... maybe work with one class this week maybe involving certain parents like our baby group - just an example. Only the baby group will bring certain materials because we will know, yes, for which ... uhm ... development skill ... uh ... do we want to work with and then we can also limit the ... uh... rubbish (laughs) in the schools ... yes.

The teachers were very creative when it came to making educational toys from waste material.

P3: To be honest, since I've made those toys that I showed you, those ones with the squares and triangle and circle, the bottles, the milk bottles ... So, what l've learned [is] that children are gonna learn, gonna use their eyes and their hands, to take a shape and put it to the, the, the bottle. You could see, okay now that child is learning. She could take the shape and put it in the same shape, like that one. So it will be, what you call it, eyehand coordination. 
Another participant made toys for the babies.

P1: I have used different sizes of medicine bottles and empty milk box[es]. I have make [made] a hole in the middle, but it is a round-shaped hole in the middle and the idea was [that] the baby [should] take any size of the medicine bottles, stick it inside that hole and then with different sizes. So that the child can also be aware of sizes because the bigger bottle will fit, and if you want to take it out of that hole, it won't be easy for the baby to take it out. So that was also the small muscles development for me. And also I have tried with this [a] 10-month [old] baby and the baby was just starting to grab all the bottles at the same time and then throw them again on the floor and bit that box. So, for me it was like a physical development that was happening. Also, the intellectual [development] of the baby because he/she could see that there is a different [difference] of these bottles, the one is smaller, the one is bigger than the others.

One of the participants came up with the idea of creating children's games that require no apparatus.

P2: I'm thinking about something like hopscotch, for example. You know we can even draw it and give a brief explanation of how to play the game.

Another participant added that hopscotch can be used to develop number sense, recognise colours and shapes and even letters, depending on the age of the children.

It was argued that it would be valuable if role-players were to appreciate and respect the principles of Ubuntu. Not only does the Ubuntu philosophy form part of the knowledge and wisdom of Afrocentric policies, it also embodies a collaborative care ethic (Lefa, 2015). Mamanzi (2020) concurs, arguing that the cohesiveness of societies is often tested in times of crisis and that South Africa could therefore respond to COVID-19 as a social action aimed at working in unity for a significant impact. We further realised that proposing the idea of making recycled educational toys could be a means of involving parents in the school and the classroom. This is an issue mentioned by one principal. It was stated that of the 49 Grade Rs in the ECD centres, only three or four parents were committed to doing the activities with their children that teachers had sent home during the lockdown. The parents did not understand, were not interested or were too lazy to do the activities with their children:

P2: Out of 49 Grade Rs, only three parents responded positively and the other, the other one said: "Ma'am, I don't understand anything here. I don't know how to match and sort and ... uh ... you know all those activities." And we realise and decide that we are not going to send any work home because the parents either doesn't [do not] have interest or they, I don't know, but ja, it is not good. We are worried that our Grade R learners are not ready.

One participant indicated that at her centre they decided to tell the parents what to bring to prevent them from bringing unnecessary items to the recycling project.

P2: We have decided to make a list of things that we want them to bring. So I must still draft, maybe like ... uhm ... the containers of the eggs or the egg shells or maybe the bottles, $2 \mathrm{~L}$ bottles of cool drink and so forth.

The ALS argued that collaboration could lead to incidental learning and to stimulating the holistic needs of children. It was decided that pictures with information on the purpose and use of recycled educational toys would be placed above the different containers. This would help the parents to understand the purpose of the activity. It will further encourage them to start thinking differently about waste materials before dumping these in the dustbin. Involving 
parents in the making of toys is also seen as part of building relationships between parents and the school. With this initiative, parents and caregivers are actively engaged by participating in the making of toys and, while in the process of making the toys, teachers use concepts such as cognitive, physical, emotional and social development. Given that during the lockdown parents and caregivers became important contributors to the holistic development of young children, it was explored how an awareness of the principles of the African Ubuntu philosophy could be used to contribute to the holistic education of young children.

\section{LIMITATIONS}

The findings of this study are limited in the sense that they cannot be generalised to other contexts because they only include the experiences of three rural ECCE centres. Meeting faceto-face to develop knowledge and skills within a PALAR approach helps the process of working collaboratively and learning while investigating a topic. The COVID-19 regulations made it impossible for the ALS to meet face-to-face. We therefore had to re-think data generation when the COVID-19 pandemic was declared a national disaster. The ALS was limited to online sessions via Zoom. Sessions had a time limit, interruptions due to connectivity problems occurred and valuable non-verbal communication was lost. Despite the mentioned limitations, we all learnt a great deal from one another and moreover gained a better understanding of the diverse contexts and of the challenges presented by the pandemic.

\section{CONCLUSION}

It is widely accepted that in the early years of a child's life, positive educational experiences and stimulating environments are critical for children's future personal and academic success (UNICEF, 2019). Finding opportunities to improve access and quality education in ECCE centres in SA should thus be regarded a high priority. In fact, researchers honour quality ECCE programmes as the first step in the education ladder. They argue that the right kind of investments could certainly cultivate potential within young children and serve to bridge the social-equity gap from a very young age.

The findings suggested that the lack of informative guidelines, relevant psychosocial support and a lack of resources during lockdown in the three Bafenyi centres widened the already considerable education gap of all children younger than five years of age. In addition, many parents from this community experienced challenges in respect of supporting children academically or financially. The findings suggested that the three Bafenyi ECCE centres could be creative about the way they develop collaborative educational interventions to stimulate the holistic development of young children. This idea is in line with the goal of PALAR research, namely that of assisting participants with a skill of lifelong learning beyond the scope of a particular research project (Wood, 2020).

It was suggested that it could be valuable if parents, teachers and caregivers from the three Bafenyi centres were to appreciate and respect the principles of Ubuntu. Not only would such an action respect the wisdom of Afrocentric philosophies, but it would moreover acknowledge the idea put forward by Ndebele and Sikuza (2020:1-3) that the COVID-19 pandemic is an invitation to all South Africans to remember familiar values and to turn these into one of "our great strengths". Given that the Ubuntu philosophy involves characteristics such as collaboration, social responsibility and sharing, it was argued that involving the communities of the three Bafenyi ECCE centres in the making of educational toys from recycled materials 
could be a first step towards acknowledging the human worth in communal relationships. Ubuntu was thus not seen as a magical agenda to make COVID-19 challenges disappear, but the ALS agreed with Oladokun (2020) that there certainly is no more opportune moment for a collaborative approach than the present.

Given the multitude of factors that could potentially influence the holistic development of young children, it becomes apparent that, even during a pandemic, it is key that ways be found to harness the precious early years while aiming not only to be mindful of children's needs but also to lay the foundation for a sustainable future. It is seen as a means of contributing to the building of relationships. More than ever, teachers, parents and caregivers should now join hands to strengthen, develop and support the holistic development of young children.

\section{ACKNOWLEDGEMENTS, COMPETING INTERESTS AND FUNDING INFORMATION}

The authors would like to thank the project participants. We also gratefully acknowledge funding from the CARN Research Foundation (Susan Noffke Award) and COMBER NWU.

\section{REFERENCES}

Afrika Tikkun. 2020. Ubuntu: The philosophy we need to follow right now. Available at Ubuntu - The philosophy we need to all follow right now! - Afrika Tikkun South Africa [Accessed 5 January 2021].

Bafenyi Trust. 2021. Our vision. Available at Our Vision - Bafenyi Trust [Accessed 4 January 2021].

Barker, J. \& Misselhorn, M. 2014. Informal settlements: Informal early childhood development centres. Available at http://thehda.co.za/pdf/uploads/multimedia/ISU_Guidelines_Informal_ Early_Childhood_Development_Centres_in_Informal_Settlements-ilovepdf-compressedcompressed.pdf [Accessed 20 October 2020].

Bennett, J. \& Palaiologou, I. 2016. Personal, social and emotional development. In I. Palaiologou (Ed.). The early years foundation stage: Theory and practice (pp. 345-365). Los Angeles: Sage.

Bertram, C. \& Christiansen, I. 2020. Understanding research: An introduction to reading research, second edition. Pretoria: Van Schaik.

Bondai, B. \& Kaputa, T.M. 2016. Reaffirming Ubuntu/unhu mainstreaming in the education curricula: a panacea for sustainable educational change in Southern Africa. International Journal of Academic Research and Reflection, 4(6): 37-44.

Braun, V. \& Clarke, V. 2013. Successful qualitative research: A practical guide for beginners. London: Sage.

Buheji,M., Hassani, A., Ebrahim, A., Da Costa Cunha, K., Jahrami, H., Baloshi, M. \& Hubail, S. 2020. Children and coping during Covid-19: A scoping review of bio-psycho-social factors. International Journal of Applied Psychology, 10(1): 8-15. https://doi.org/10.5923/j. ijap.20201001.02

Chen, P., Mao, L., Nassis, G.P., Harmer, P., Ainsworth, B.E. \& Li, F. 2020. Coronavirus disease (COVID-19): The need to maintain regular physical activity while taking precautions. Journal of Sport and Health Science, 9(2): 103-104. https://doi.org/10.1016/j.jshs.2020.02.001 
Cohen, L., Manion, L. \& Morrison, K. 2013. Research methods in education. London: Routledge Falmer.

Devercelli, A. 2020. Supporting the youngest learners and their families in the COVID-19 (Coronavirus) response. Available at https://blogs.worldbank.org/education/supportingyoungest-learners-and-their-families-covid-19-coronavirus-response [Accessed 8 October 2020].

Eastern Cape News. 2020. EC township in line for a slice of R4m virus emergency fund. Available at https://www.easterncapeindustrialnews.co.za/news/ec-township-in-line-for-aslice-of-r4m-virus-emergency-fund [Accessed 20 October 2020].

Egan, S. 2020. Lockdown effects - 'not the same child at all'. Scéalta - The early childhood Ireland blog. Available at https://www.earlychildhoodireland.ie/blog/lockdown-effects-not-thesame-child-at-all/ [Accessed 8 October 2020].

Education, Training and Development Practices Sector Education and Training Authority (ETDP.SETA). 2020. Early childhood development sector skills plan 2019-2020. Available at http://www.etdpseta.org.za/education/sites/default/files/2020-06/Early-ChildhoodDevelopment-Sector-Skills-Plan-2019-2020-Update.pdf [Accessed 21 October 2020].

Flynn, K. 2020. Covid-19 policy responses to early childhood development (ECD). Human Sciences Research Council Webinar. Available at http://www.hsrc.ac.za/uploads/ pageContent/12207/COVID-19\%20Policy\%20Reponses\%20HSRC\%20Preso.pdf [Accessed 18 August 2020].

Fourie, E. \& Kgalenga, R. 2014. An investigation into practical interventions for quality early childhood development: The Siyakhulisa Project. International Journal of Educational Science, 6(2): 287-296. https://doi.org/10.1080/09751122.2014.11890140

Gumbi, E.B. 2019. Indigenous fundamentals for early childhood development in a shared educational praxis for the $21^{\text {st }}$ century: Pedagogical perspective on a multi-cultural race. Gender and Behaviour, 17(3): 13645-13653.

Harrison, G.D. 2020. A snapshot of early childhood care and education in South Africa: institutional offerings, challenges and recommendations. South African Journal of Childhood Education, 10(1): 1-10. https://doi.org/10.4102/sajce.v10i1.797

Herr, K. \& Anderson, G.L. 2005. The action research dissertation: a guide for students and faculty. Thousand Oaks, CA: Sage. https://doi.org/10.4135/9781452226644

Leedy, P.D. \& Ormrod, J.E. 2015. Practical research: Planning and design, eleventh edition. Boston: Pearson.

Lefa, B.J. 2015. The African philosophy of Ubuntu in South African education. Studies in Philosophy and Education, 1(1): 1-15.

Makhubu, L. 2020. Lockdown brings concern about impact on early childhood development. Available at https://www.iol.co.za/pretoria-news/news/lockdown-brings-concern-aboutimpact-on-early-childhood-development--ef0208cb-dc6e-478e-9096-68866e2eaf38. [Acessed 8 October 2020].

Mamanzi, V. 2020. Ubuntu and solidarity in times of Covid-19: challenges and contradictions as communities grapple with ways of being and doing during a pandemic. Available at https:// www.csagup.org/2020/05/28/ubuntu-and-solidarity-in-times-of-covid-19-challenges-and- 
contradictions-as-communities-grapple-with-ways-of-being-and-doing-during-a-pandemic/ [Accessed 20 October 2020].

Masweneng, K. 2020. If not rescued, 15\% of SA's crèches could close down, warns NGO. Available at https://www.sowetanlive.co.za/news/south-africa/2020-06-26-if-not-rescued-15of-sas-creches-could-close-down-warns-ngo/ [Accessed 21 October 2020].

McAreavey, R. \& Das, C. 2013. A delicate balancing act: Negotiating with gatekeepers for ethical research when researching minority communities. International Journal of Qualitative Methods, 12(1): 113-131. https://doi.org/10.1177/160940691301200102

Mugumbate, J. \& Chereni, A. 2019. Using African ubuntu theory in social work with children in Zimbabwe. African Journal of Social Work, 9(1): 27-34.

Mushaandja, J. 2015. Unpack $U(B) U n t u$. Available at Unpack $U(b)$ untu - The Namibian [Accessed 23 December 2020].

Ndebele, J. \& Sikuza, J. 2020. Africa Month, Covid 19 and our shared humanity: Ubuntu in a time of crisis. Available at https://www.mandelarhodes.org/ideas/africa-month-covid-19-andour-shared-humanity-ubuntu-in-a-time-of-crisis/ [Accessed 13 October 2020]

News24. 2019. Edutainment from recyclables. Available at https://www.news24.com/news24/ southafrica/local/maritzburg-fever/edutainment-from-recyclables-20191127 [Accessed 10 August 2020].

Norren, D. E. 2014. The nexus between Ubuntu and global public goods: its relevance for the post 2015 development agenda. Development Studies Research: An Open Access Journal, 1(1): 255-266. https://doi.org/10.1080/21665095.2014.929974

Oladokun, V. 2020. Covid-19: Africa urgently needs an ubuntu plan. Health \& Welfare News Africa. Available at https://www.bizcommunity.africa/Article/410/629/202141.html [Accessed 13 October 2020].

Peckham, T. 2017. Developing school readiness. Creating lifelong learners. Los Angeles: Sage. https://doi.org/10.4135/9781526419286

Pedro, A., Mthimunye, B. \& Bust, E. 2020. How lockdown could affect South Africa's children with special needs. Available at How lockdown could affect South Africa's children with special needs | Health24 (news24.com) [Accessed 3 January 2020].

Phasha, N. 2016. Understanding inclusive education from an Afrocentric perspective. In N. Phasha \& J. Condy (Eds). Inclusive education: An African perspective (pp. 3-24). Cape Town: Oxford.

Rampke, B. 2016. Interconnectedness, healing \& harmony. The application of Ubuntu in peach research and in Namibian-German postcolonionial disputes emerging from the return of human remains. MEd dissertation. Available at Microsoft Word - Thesis_final1.docx (core. ac.uk) [Accessed 23 December 2020].

Singakwenza. 2020. We can do it. Early childhood education. Available at http://www. singakwenza.co.za/our-story/ [Accessed on 2 January 2021].

South African Early Childhood Review. 2019. South African early childhood review. Available at http://www.ci.uct.ac.za/sites/default/files/image_tool/images/367/SAECR_2019_12_09_2019_online_pages_0.pdf [Accessed 20 October 2020]. 
South Africa. Department of Education. 2001. Meeting the challenge of early childhood development in South Africa. Education White Paper 5 on early childhood education. Available at Education White Paper 5 on Early Childhood Education | South African Government (www. gov.za) [Accessed 8 October 2020].

South Africa. Department of Basic Education. 2001. Early childhood development. Available at https://www.gov.za/about-sa/what-early-childhood-development [Accessed 20 October 2020].

Takyi-Amoako, E.J. \& Assié-Lumumba, N.T. 2018. Re-visioning education in Africa. Ubuntuinspirededucationforhumanity. NewYork:Palgrave. https://doi.org/10.1007/978-3-319-70043-4

United Nations Educational Scientific and Cultural Organisation (UNESCO). 2019. Early childhood care and education. Available at https://en.unesco.org/themes/early-childhoodcare-and-education [Accessed 20 October 2020].

United Nations Educational Scientific and Cultural Organisation (UNESCO). 2020a. New drive to protect early childhood education in the context of the COVID 19 crisis. Available at https://en.unesco.org/news/new-drive-protect-early-childhood-education-context-covid-19crisis [Accessed 7 October 2020].

United Nations Educational Scientific and Cultural Organisation (UNESCO). 2020b. The impact of COVID-19 on ECCE sector: Lesson learned and promising practices from the AsiaPacific. Available at https://en.unesco.org/sites/default/files/unesco-covid-19_ed-webinar-14unesco-bangkok.pdf [Accessed 7 October 2020].

United Nations Educational Scientific and Cultural Organisation (UNESCO). 2020c. UNESCO rallies international organisations, civil society and private partners in a broad collation to ensure \#LearningNeverStops. Available at https://en.unesco.org/news/unesco-ralliesinternational-organizations-civil-society-and-private-sector-partners-broad [Accessed 7 October 2020].

United Nations International Children's Emergency Fund (UNICEF). 2020. Early childhood development and COVID-19. Available at https://data.unicef.org/topic/early-childhooddevelopment/covid-19/ [Accessed 7 October 2020].

Warwick, P., Warwick, A. \& Nash, K. 2018. Towards a pedagogy of hope: Sustainability education in the early years. In V. Huggins \& D. Evans (Eds). Early childhood education and care for sustainability. International perspectives (pp 13-28). London: Routledge. https://doi. org/10.4324/9781315295855-3

Wilemon, Z. 2020. Founder reflections. Ubuntu life. Available at https://www.ubuntu.life/blogs/ news/from-our-founder [Accessed 12 October 2020].

Wood, L. 2020. Participatory action learning and action research: Theory, practice and process. London: Routledge. https://doi.org/10.4324/9780429441318

Wood, L. \& Zuber-Skerritt, O. 2013. PALAR as a methodology for community engagement by faculties of education. South African Journal of Education, 33(4): 1-15. https://doi. org/10.15700/201412171322

Wooldridge, M. 2020. Ubuntu should be at the centre of our response. Available at https:// mg.co.za/coronavirus-essentials/2020-05-12-ubuntu-should-be-at-the-centre-of-ourresponse-to-covid-19/ [Accessed 7 October 2020]. 
Zuber-Skerritt, O. 2011. Action leadership: Towards a participatory paradigm. London: Springer. https://doi.org/10.1007/978-90-481-3935-4

Zuber-Skerritt, O. 2019. Integrating action learning with action research (ALAR). In O. ZuberSkerritt \& L. Wood (Eds). Action learning and action research: Genres and approaches (pp. 69-82). Bingley: Emerald Publishing. https://doi.org/10.1108/978-1-78769-537-520191008 